\title{
PERUBAHAN POLA KONSUMSI RUMAH TANGGA SAAT COVID-19 (STUDI KASUS DI KELURAHAN DRAJAT, KOTA CIREBON, JAWA BARAT)
}

\author{
Afriliyendra Putri Bestari*, Trisna Insan Noor \\ Fakultas Pertanian, Universitas Padjadjaran \\ Jl. Raya Bandung Sumedang Jatinangor, Sumedang 45363 \\ *Corresponding author: afriliyendrap@gmail.com
}

\begin{abstract}
Covid-19 is a global pandemic that impacts all sectors. Household is one of the sectors that impacted, and the conditions during the Covid-19 pandemic have been changing especially a decrease in the household consumption expenditure. The purpose of this research is to understand the household food consumption pattern and its relation with the characteristics of respondents. This research used a quantitative descriptive design with a survey method that located in RW 02 Drajat Sub-district, Cirebon City, on October-November 2020. The numbers of research samples are 61 respondents consisting of housewives. The analysis method used is crosstabs method. The results showed that the average age of the respondents was 15-64 years old, the number of family members is 3 persons, the household income per month before and during Covid-19 are IDR 2,000,000-IDR 3,000,000 and < IDR 1,000,000, the education achieved is senior high school or vocational high school, the job is as a housewife, and 62,30\% jobs affected due to Covid-19. The household consumption patterns have been changing specifically a decrease in household food consumption expenditure on almost all food commodities except for consumption of vegetable commodities due to the rising prices. However, the amount of food and other non-food consumption tends to remain and decrease. The results showed that the household income and husband's job have a relation with the household consumption patterns changing, it is indicated by the value of Asymp. Sig. (2-sided) $<0.05$, while other variables have no relation with the household consumption patterns changing.
\end{abstract}

Keywords: Covid-19, consumption, food and non-food, household

Abstrak: Covid-19 merupakan pandemic global yang berdampak di semua sektor,
rumah tangga merupakan salah satu sektor yang terdampak dimana konsumsi rumah
tangga di masa pandemic Covid-19 mengalami perubahan berupa penurunan
konsumsi rumah tangga. Tujuan dari penelitian ini adalah mengetahui perubahan pola
konsumsi rumah tangga dan hubungannya dengan karakteristik responden. Penelitian
ini menggunakan desain deskriptif kuantitatif dengan metode survei. Penelitian
dilakukan di RW 02 Kelurahan Drajat Kota Cirebon pada bulan Oktober-November
2020. Jumlah sampel penelitian sebanyak 61 responden yaitu ibu rumah tangga.
Metode analisis yang digunakan adalah metode tabulasi silang (Crosstab). Hasil
penelitian menunjukkan bahwa rata-rata umur responden adalah $15-64$ tahun, rata-rata
jumlah anggota keluarga 3 orang, rata-rata pendapatan rumah tangga per bulan
sebelum dan selama Covid-19 adalah Rp2.000.000-Rp3.000.000 dan < Rp1.000.000,
pendidikan terakhir IRT adalah SMA/SMK, pekerjaan rata-rata sebagai ibu rumah
tangga, Pekerjaan Terdampak karena Covid-19 sebanyak $62,30 \%$ terdampak dan
$37,70 \%$ tidak terdampak. Perubahan pola konsumsi rumah tangga di lokasi penelitian
mengalami penurunan konsumsi pangan rumah tangga hampir pada seluruh kelompok
komoditas pangan, kecuali kelompok komoditas sayuran yang mengalami peningkatan
konsumsi. Peningkatan terjadi karena adanya jenis sayur-sayuran yang mengalami
kenaikkan harga, namun untuk jumlah konsumsi pangan dan non pangan lainnya 
cenderung tetap dan menurun. Hasil analisis Crosstab menunjukkan bahwa pendapatan rumah tangga dan pekerjaan suami memiliki hubungan dengan perubahan pola konsumsi rumah tangga, hal ini ditandai dengan nilai Asymp. Sig. (2-sided) < 0,05 . Sedangkan variabel lainnya tidak memiliki hubungan dengan perubahan pola konsumsi rumah tangga.

Kata kunci: Covid-19, konsumsi, pangan dan non pangan, rumah tangga

\section{PENDAHULUAN}

Covid-19 atau virus corona merupakan virus yang berasal dari Kota Wuhan, China bermula di akhir tahun 2019 dan sampai saat ini di tahun 2021 masih tersebar dimana-mana. Pada 11 Maret 2020, Organisasi Kesehatan Dunia (WHO) menetapkan virus corona sebagai pandemi global, karena virus ini dapat menyerang banyak orang dan terjadi di banyak tempat. Demi memutus penyebaran Covid-19, pemerintah harus mengambil langkah seperti segala kegiatan yang biasanya dilakukan di luar rumah berubah menjadi segala kegiatan dilakukan dari rumah (Rasmikayati et al., 2020). Salah satu kebijakan yang telah diambil pemerintah yaitu PSBB (Pembatasan Sosial Berskala Besar).

Kebijakan PSBB tersebut tentu berdampak terhadap semua bidang, seperti kesehatan, ekonomi, hingga interaksi sosial di masyarakat. Adanya kebijakan PSBB di satu sisi memiliki tujuan yang positif yaitu untuk memutus rantai penyebaran Covid-19 dan di sisi lain kebijakan tersebut menyebabkan perekonomian menjadi melemah, khususnya di sektor rumah tangga. (Badan Pusat Statistik, 2020), menyatakan bahwa kebijakan PSBB di Indonesia memiliki dampak secara langsung maupun tidak langsung terhadap turunnya tingkat pertumbuhan konsumsi rumah tanggga pada Triwulan I 2020 yaitu sebesar 2,84\% melambat dibanding Triwulan I 2019 yaitu sebesar 5,07\%. Artinya, pemberlakuan PSBB menjadikan masyarakat lebih berhati-hati dalam mengelola keuangannya, salah satunya dengan mengubah pola konsumsi ke arah kebutuhan pokok, seperti makanan dan minuman serta produk kesehatan.

Pola konsumsi adalah gambaran berbagai macam makanan, barang, dan jasa yang digunakan atau dihabiskan atau dikeluarkan seseorang atau sekelompok orang guna memenuhi kebutuhannya. Pola konsumsi atau pengeluaran rumah tangga dapat dibedakan menjadi pengeluaran konsumsi untuk kelompok makanan (pangan) dan kelompok bukan makanan (non pangan). Hal ini sesuai dengan pernyataan Badan Pusat Statistika (2019), dimana konsumsi pangan terdiri dari padi-padian, umbi-umbian, ikan/ udang/ cumi/ kerang, daging, telur dan susu, sayur-sayuran, kacang-kacangan, buah-buahan, minyak dan kelapa, bahan minuman, bumbu-bumbuan, konsumsi lainnya, makanan dan minuman jadi, rokok dan tembakau. Sedangkan untuk konsumsi non pangan terdiri dari perumahan dan fasilitas rumah tangga, aneka barang dan jasa, pakaian, alas kaki, dan tutup kepala, barang tahan lama, pajak, pungutan, dan asuransi, keperluan pesta dan upacara/kenduri.

Rata-rata pengeluaran per kapita sebulan menurut kelompok komoditas dan kelompok pengeluaran (rupiah) Kota Cirebon pada tahun 2018 yaitu sebesar 42,01\% untuk pangan dan $57,99 \%$ bukan pangan (Badan Pusat Statistik Kota Cirebon, 2018). Sedangkan rata-rata pengeluaran per kapita sebulan menurut kelompok komoditas dan kelompok pengeluaran (rupiah) pada tahun 2019 yaitu sebesar 41,68\% untuk pangan dan 58,32\% bukan pangan (Badan Pusat Statistik Kota Cirebon, 2019).

Anjuran pemerintah untuk tetap dirumah menjadikan masyarakat melakukan segala kegiatannya secara online. Perubahan kegiatan secara online tersebut dapat menyebabkan gaya makan seseorang atau suatu rumah tangga berubah atau dapat dikatakan adanya perubahan pola konsumsi rumah tangga. Perubahan pola konsumsi timbul karena adanya faktor-faktor yang memengaruhi, seperti dalam penelitian (Ismah, 2020; Sugiyanto dan Pintakami, 2021), disebutkan bahwa faktor-faktor yang dapat memengaruhi pola konsumsi terdiri dari jumlah anggota keluarga, umur, pendapatan, dan total pengeluaran. Sedangkan menurut Putri et al. (2019), faktor-faktor yang memengaruhi pola konsumsi salah satunya yaitu pendidikan dan pekerjaan. Pola konsumsi yang terdiri dari 
faktor pendapatan dapat dijelaskan seperti yang dinyatakan dalam teori Hukum Engel yaitu pola konsumsi keluarga dapat dipengaruhi oleh tinggi rendahnya pendapatan dan lingkungan sosialnya. Rumah tangga yang memiliki pendapatan rendah akan mengeluarkan sebagian besar pendapatannya untuk membeli kebutuhan pokok atau pangannya terlebih dahulu. Sebaliknya rumah tangga yang memiliki pendapatan tinggi akan mengeluarkan sebagian kecil saja dari total pendapatannya untuk kebutuhan pokok (Gilarso, 2008).

Oleh karena itu, penelitian ini dilakukan untuk melihat bagaimana perubahan pola konsumsi rumah tangga saat Covid-19 dan hubungannya dengan karakteristik responden di RT 03 dan 04 RW 02 Kelurahan Drajat Kota Cirebon.

\section{METODE PENELITIAN}

Penelitian dilaksanakan pada bulan OktoberNovember 2020 di RT 03 dan 04 RW 02 Kelurahan Drajat Kota Cirebon. Lokasi penelitian dipilih secara sengaja (purposive) dengan pertimbangan karena lokasi penelitian termasuk salah satu daerah yang pernah berstatus zona merah Covid-19 dan terdapat warga positif dan meninggal dunia karena Covid-19.

Desain penelitian yang digunakan adalah deskriptif kuantitatif dengan metode survei. Sumber data yang digunakan adalah data primer dan sekunder. Data primer diperoleh dari pengisian kuesioner dan wawancara kepada responden di lokasi penelitian. Sedangkan data sekunder diperoleh dari Badan Pusat Statistik, buku, jurnal, skripsi, dan media informasi lainnya yang berhubungan dengan penelitian.

Responden dalam penelitian ini adalah ibu rumah tangga di RT 03 dan 04 RW 02 Kelurahan Drajat Kota Cirebon. Teknik pengambilan sampel yang digunakan dalam penelitian ini adalah simple random sampling atau pengambilan anggota sampel dari populasi yang dilakukan secara acak (Sugiyono, 2017). Populasi dalam penelitian adalah ibu rumah tangga di RT 03 dan 04 RW 02 Kelurahan Drajat Kota Cirebon yang berjumlah $157 \mathrm{KK}$. Penelitian menggunakan rumus Slovin untuk menentukan sampel responden. Berdasarkan rumus slovin tersebut dengan nilai kritis $10 \%$, maka diperoleh sampel sebanyak 61 responden.

Analisis data menggunakan analisis statistika deskriptif dan analisis tabulasi silang atau Crosstabs. Analisis-analisis tersebut digunakan untuk menggambarkan perubahan pola konsumsi rumah tangga dan hubungannya dengan karakteristik responden.

\section{HASIL DAN PEMBAHASAN}

\section{Gambaran Umum}

Kelurahan Drajat merupakan salah satu kelurahan yang ada di Kota Cirebon, Jawa Barat. Secara geografis Kelurahan Drajat memiliki batas-batas wilayah sebelah utara (Kelurahan Kesambi), barat (Kelurahan Jagasatru), selatan (Kelurahan Larangan) dan timur (Kelurahan Sunyaragi). Secara administrasi Kelurahan Drajat Kota Cirebon terdiri dari 9 RW (Rukun Warga) dan 62 RT (Rukun Tetangga), dimana pada RW 02 (Rukun Warga) memiliki 5 RT (Rukun Tetangga).

\section{Karakteristik Responden}

Karakteristik responden dalam penelitian di Kelurahan Drajat Kota Cirebon ini untuk menggambarkan subjek penelitian yaitu ibu rumah tangga. Jumlah responden sebanyak 61 ibu rumah tangga. Karakteristik responden yang dideskripsikan terdiri dari umur, jumlah anggota keluarga, pendapatan rumah tangga, pendidikan, pekerjaan suami dan istri, dan Pekerjaan Terdampak karena Covid-19 dapat dilihat pada Tabel 1 .

Hasil penelitian menunjukkan bahwa sebagian besar responden atau umur ibu rumah tangga merupakan kelompok umur produktif, yaitu sebesar 90,2\% berumur antara 15-64 tahun. Responden di lokasi penelitian sebagian besar memiliki jumlah anggota keluarga sebanyak 3 orang dengan persentase 37,7\%. Selain itu, tingkat pendidikan formal terbesar yang ditempuh responden yaitu tingkat pendidikan Sekolah Menengah Atas (SMA) atau Sekolah Menengah Kejuruan (SMK) sebesar $45,9 \%$. Kemudian, pekerjaan terdampak Covid-19 sebesar $62,3 \%$ terdampak pekerjaannya dan $37,7 \%$ tidak terdampak.

Rata-rata pendapatan rumah tangga per bulan terbesar yang dimiliki rumah tangga di RT 03 dan RT 04 RW 02 Kelurahan Drajat 
Tabel 1. Karakteristik responden

\begin{tabular}{|c|c|c|c|c|}
\hline Deskripsi & \multicolumn{4}{|c|}{ Persentase (\%) } \\
\hline \multicolumn{5}{|l|}{ Umur Responden (Tahun) } \\
\hline a. $<15$ & \multicolumn{4}{|c|}{0} \\
\hline b. $15-64$ & \multicolumn{4}{|c|}{90,2} \\
\hline c. $\geq 65$ & \multicolumn{4}{|c|}{9,8} \\
\hline \multicolumn{5}{|l|}{ Jumlah Anggota Keluarga (orang) } \\
\hline a. 1 & \multicolumn{4}{|c|}{9,8} \\
\hline b. 2 & \multicolumn{4}{|c|}{9,8} \\
\hline c. 3 & \multicolumn{4}{|c|}{37,7} \\
\hline d. 4 & \multicolumn{4}{|c|}{24,6} \\
\hline e. 5 & \multicolumn{4}{|c|}{13,1} \\
\hline f. 6 & \multicolumn{4}{|c|}{3,3} \\
\hline g. 7 & \multicolumn{4}{|c|}{1,6} \\
\hline \multicolumn{5}{|l|}{ Pendidikan Responden } \\
\hline a. $\quad$ Tidak Sekolah & \multicolumn{4}{|c|}{0} \\
\hline b. SD & \multicolumn{4}{|c|}{27,9} \\
\hline c. SMP & \multicolumn{4}{|c|}{18} \\
\hline d. SMA/SMK & \multicolumn{4}{|c|}{45,9} \\
\hline e. Perguruan Tinggi & \multicolumn{4}{|c|}{8,2} \\
\hline \multicolumn{5}{|c|}{ Pekerjaan Terdampak karena Covid-19 } \\
\hline a. $\quad$ Tidak Terdampak & \multicolumn{4}{|c|}{37,7} \\
\hline b. Terdampak & \multicolumn{4}{|c|}{62,3} \\
\hline Pendapatan Rumah Tangga (Rp) & \multirow{2}{*}{\multicolumn{2}{|c|}{$\frac{\text { Sebelum Covid-19 }}{246}$}} & \multicolumn{2}{|c|}{ Selama Covid-19 } \\
\hline a. $\quad<1.000 .000$ & & & \multicolumn{2}{|c|}{39,3} \\
\hline b. $\quad 1.000 .000-2.000 .000$ & \multicolumn{2}{|c|}{23} & \multicolumn{2}{|c|}{3,23} \\
\hline c. $2.000 .000-3.000 .000$ & \multicolumn{2}{|c|}{29,5} & & \\
\hline d. $3.000 .000-4.000 .000$ & & & & \\
\hline e. $>4.000 .000$ & & & & \\
\hline & Sebel & id-19 & $\mathrm{Sel}$ & \\
\hline Pekerjaan Rumah Tangga & Suami & Istri & Suami & Istri \\
\hline a. $\mathrm{PNS}$ & 3,3 & 1,6 & 3,3 & 1,6 \\
\hline b. BUMN & 1,6 & 0 & 1,6 & 0 \\
\hline c. Swasta & 29,5 & 8,2 & 29,5 & 8,2 \\
\hline d. Wiraswasta & 42,6 & 21,3 & 41 & 19,7 \\
\hline e. IRT & 0 & 63,9 & 0 & 65,6 \\
\hline f. $\quad$ ART & 0 & 4,9 & 0 & 4,9 \\
\hline g. Tidak Bekerja/Tidak Ada & 23 & 0 & 24,6 & 0 \\
\hline
\end{tabular}

Sumber: Data Primer, 2020

Kota Cirebon yaitu sebelum Covid-19 sebesar Rp2.000.000 - Rp3.000.000 atau 29,5\% sedangkan pendapatan rumah tangga selama Covid-19 yaitu sebesar $<$ Rp1.000.000 atau $39,3 \%$. Kemudian persentase tertinggi jenis pekerjaan istri sebelum dan selama Covid-19 didominasi oleh sebagai IRT atau Ibu Rumah Tangga sebesar $63,9 \%$ dan $65,6 \%$. Sedangkan persentase jenis pekerjaan tertinggi yang dimiliki suami responden adalah jenis pekerjaan wiraswasta baik sebelum Covid-19 maupun selama Covid-19 yaitu sebesar $42,6 \%$ dan $41 \%$.

\section{Perubahan Pola Konsumsi Rumah Tangga}

Kemampuan menghabiskan atau menggunakan makanan atau barang dan jasa yang dapat menggambarkan bagaimana pola konsumsi rumah tangga. Pola konsumsi rumah tangga adalah gambaran berbagai macam jenis kegiatan menghabiskan atau menggunakan makanan atau barang dan jasa atau susunan berbagai macam pengeluaran yang digunakan untuk kebutuhan rumah tangga (Sari et al., 2020).

Jenis konsumsi rumah tangga terdiri dari konsumsi pangan dan non pangan. Konsumsi pangan adalah susunan makanan yang mencakup jenis dan jumlah bahan makanan yang umum dikonsumsi penduduk dalam 
jangka waktu tertentu. Konsumsi pangan terdiri dari bahan makanan pokok seperti beras, jagung, dan tepung terigu, ubi. Lauk pauk seperti ikan, udang, cumi, kerang, daging, telur, dan sayuran. Bahan penunjang seperti minyak goreng, bumbu dapur. Bahan minuman seperti teh, kopi, gula, dan lain-lain. Sedangkan konsumsi non pangan adalah berupa biaya yang dikeluarkan untuk membeli kebutuhan rumah tangga selain dari makanan. Konsumsi non pangan terdiri dari konsumsi atau pengeluaran untuk listrik air, bahan bakar minyak (BBM), LPG, biaya pendidikan, kesehatan, transportasi, biaya untuk berpergian atau rekreasi, biaya kebutuhan sehari-hari seperti sabun mandi, sampo, pasta gigi, dan lain-lain. Pola konsumsi rumah tangga tersebut dapat digambarkan pada Tabel 2 yang menjelaskan rata-rata konsumsi rumah tangga di RT 03 dan 04 RW 02 Kelurahan Drajat Kota Cirebon.

Berdasarkan hasil penelitian pada Tabel 2 dapat diketahui bahwa alokasi biaya yang dikeluarkan rumah tangga tersebut adalah untuk konsumsi non pangan lebih besar dibandingkan konsumsi pangan baik sebelum dan selama Covid-19, dengan demikian dapat dikatakan bahwa masyarakat di RT 03 dan 04 RW 02 Kelurahan Drajat Kota Cirebon termasuk masyarakat yang sejahtera. Hal ini sesuai dengan pendapat Mulyanto (2005) yang

$\underline{\text { Tabel 2. Perubahan pola konsumsi rumah tangga }}$

\begin{tabular}{|c|c|c|c|c|c|}
\hline \multirow{2}{*}{ No. } & \multirow{2}{*}{ Kelompok Komoditas } & \multicolumn{2}{|c|}{$\begin{array}{c}\text { Total Rata-rata Pengeluaran } \\
\text { Konsumsi RT Per Bulan } \\
\text { (Rp) }\end{array}$} & \multicolumn{2}{|c|}{$\begin{array}{c}\text { Perubahan Harga dalam } \\
\text { Pengeluaran Konsumsi RT Per } \\
\text { Bulan } \\
\end{array}$} \\
\hline & & $\begin{array}{l}\text { Sebelum } \\
\text { Covid-19 }\end{array}$ & $\begin{array}{l}\text { Selama } \\
\text { Covid-19 }\end{array}$ & $\begin{array}{l}\text { Total Perubahan } \\
\text { (Rp) }\end{array}$ & $\begin{array}{c}\text { Total } \\
\text { Perubahan }(\%)\end{array}$ \\
\hline 1. & Padi-padian & 195.656 & 182.361 & $-13.295,08$ & $-0,11 \%$ \\
\hline 2. & Umbi-umbian & 8.598 & 7.656 & $-942,62$ & $-0,18 \%$ \\
\hline 3. & Ikan/Udang/Cumi/Kerang & 30.754 & 24.336 & $-6.418,03$ & $-0,80 \%$ \\
\hline 4. & Daging & 66.164 & 53.488 & $-12.676,23$ & $-0,31 \%$ \\
\hline 5. & Telur dan Susu & 64.874 & 59.374 & $-5.500,00$ & $-0,14 \%$ \\
\hline 6. & Sayur-sayuran & 74.615 & 76.164 & $1.549,18$ & $0,04 \%$ \\
\hline 7. & Kacang-kacangan & 17.262 & 16.713 & $-3,18$ & $-0,05 \%$ \\
\hline 8. & Buah-buahan & 31.467 & 26.607 & $-4.860,66$ & $-0,25 \%$ \\
\hline 9. & Minyak dan Kelapa & 29.952 & 28.686 & $-1.266,39$ & $-0,07 \%$ \\
\hline 10. & Bahan Minuman & 49.098 & 48.156 & $-942,62$ & $-0,03 \%$ \\
\hline 11. & Bumbu-bumbuan & 38.148 & 36.443 & $-1.704,92$ & $-0,07 \%$ \\
\hline 12. & Konsumsi Lainnya & 36.377 & 32.861 & $-3.516,39$ & $-0,16 \%$ \\
\hline 13. & Makanan \& minuman jadi & 37.385 & 32.090 & $-5.295,08$ & $-0,23 \%$ \\
\hline \multirow[t]{2}{*}{14.} & Rokok dan tembakau & 67.910 & 63.992 & $-3.918,03$ & $-0,09 \%$ \\
\hline & Jumlah Pangan & 748.261 & 688.925 & -59.336 & $-0,13 \%$ \\
\hline 15. & $\begin{array}{l}\text { Perumahan dan fasilitas rumah } \\
\text { tangga }\end{array}$ & 527.303 & 498.246 & -29.057 & $-0,006 \%$ \\
\hline \multirow{2}{*}{$\begin{array}{l}16 . \\
17 .\end{array}$} & Aneka barang dan jasa & 444.697 & $243 k .975$ & -200.721 & $-0,6 \%$ \\
\hline & $\begin{array}{l}\text { Pakaian, alas kaki, dan tutup } \\
\text { kepala }\end{array}$ & 14.098 & 12.213 & -1.885 & $-1,00 \%$ \\
\hline \multirow{2}{*}{$\begin{array}{l}18 . \\
19 .\end{array}$} & Barang tahan lama & 0 & 0 & 0 & 0 \\
\hline & Pajak, pungutan, dan asuransi & 0 & 0 & 0 & 0 \\
\hline \multirow[t]{2}{*}{20.} & $\begin{array}{l}\text { Keperluan pesta dan upacara/ } \\
\text { kenduri }\end{array}$ & 0 & 0 & 0 & 0 \\
\hline & Jumlah Non Pangan & 1.024 .951 & 768.992 & -255.959 & $-0,41 \%$ \\
\hline \multicolumn{2}{|r|}{ Jumlah Konsumsi Rumah Tangga } & 1.773 .212 & 1.457 .917 & -315.295 & $-0,54 \%$ \\
\hline
\end{tabular}

Sumber: Data Primer, 2020 
menyatakan bahwa semakin tinggi pengeluaran konsumsi pangan, maka semakin rendah tingkat kesejahteraan rumah tangga tersebut. Sebaliknya, semakin kecil jumlah pengeluaran konsumsi pangan maka rumah tangga tersebut semakin sejahtera.

Dapat dilihat pada Tabel 7 bahwa ratarata konsumsi pangan rumah tangga per bulan sebelum Covid-19 sebesar Rp748.261 dan selama Covid-19 sebesar Rp688.925, dengan kata lain rata-rata konsumsi pangan sebelum dan selama Covid-19 mengalami perubahan yaitu adanya penurunan konsumsi sebesar Rp59.336 atau 0,13\%. Jenis konsumsi atau pengeluaran rumah tangga komoditas pangan terbesar baik sebelum dan selama Covid-19 adalah kelompok komoditas padi-padian yaitu sebesar Rp195.656 dan Rp182.361, dimana padi-padian salah satunya terdiri dari beras yang masih menjadi kebutuhan pokok masyarakat di lokasi penelitian karena memiliki jumlah pengeluaran terbesar. Kelompok komoditas padi-padian juga mengalami penurunan konsumsi sebesar Rp13.295,08 atau $0,11 \%$. Perubahan penurunan konsumsi padipadian seperti beras dikarenakan harga yang mereka beli selama Covid-19 cenderung lebih murah dibandingkan sebelum Covid-19 walaupun jumlah yang di konsumsinya tetap, hal tersebut ditunjukkah dari responden yang membeli beras dengan harga sebelum Covid-19 Rp11.000 sedangkan selama Covid-19 menjadi Rp10.000. Berbeda dengan jumlah jagung dan tepung terigu yang dikonsumsi cenderung menurun namun harga yang dibeli lebih mahal, tetap, dan lebih murah.

Selain itu, rata-rata jumlah konsumsi pangan sebelum dan selama Covid-19 terbesar kedua adalah kelompok komoditas sayursayuran yaitu sebesar Rp74.615 dan Rp76.164. Berbeda dengan kelompok komoditas padipadian, untuk sayur-sayuran justru mengalami peningkatan konsumsi rumah tangga yaitu sebesar Rp1.549,18 atau 0,04\%. Hal ini disebabkan karena harga kelompok komoditas sayur-sayuran cenderung mengalami peningkatan, sedangkan jumlah yang dikonsumsi tetap dan menurun. Naiknya harga sayur-sayuran terjadi hampir pada seluruh jenis sayur-sayuran terutama bawang putih dan cabai-cabaian, hal ini membuat para ibu rumah tangga merasa tertekan karena salah satu bahan atau bumbu masakan utama mengalami peningkatan harga, sehingga para ibu rumah tangga harus mengurangi jumlah konsumsi lainnya selain sayur-sayuran. Kemudian, ratarata konsumsi pangan dengan jumlah pengeluaran terkecil sebelum dan selama Covid-19 terjadi pada kelompok komoditas umbi-umbian yaitu sebesar Rp8.598 dan Rp7.656. Kelompok komoditas umbi-umbian juga mengalami perubahan yaitu adanya penurunan sebesar Rp942,62 atau 0,18\%, penurunan ini terjadi karena jumlah yang dikonsumsi berkurang sedangkan untuk harga cenderung tetap dan murah dibandingkan kelompok komoditas pangan lainnya. Penurunan konsumsi pangan juga terjadi pada kelompok komoditas ikan/udang/cumi/kerang, daging, telur dan susu, kacang-kacangan, buahbuahan, minyak dan kelapa, bahan minuman, bumbu-bumbuan, konsumsi lainnya, makanan dan minuman jadi, serta rokok dan tembakau. Penurunan tersebut memiliki angka yang berbeda-beda sesuai kelompok komoditasnya, namun rata-rata penurunan konsumsi tersebut terjadi karena jumlah yang dikonsumsi cenderung menurun dan harga yang dibeli responden cenderung menjadi lebih murah.

Jenis konsumsi rumah tangga selanjutnya yaitu konsumsi non pangan. Rata-rata konsumsi non pangan rumah tangga sebelum dan selama Covid-19 yaitu sebesar Rp1.024.951 dan Rp768.992. Dapat dikatakan bahwa rata-rata konsumsi kon pangan rumah tangga di lokasi penelitian mengalami perubahan pula yaitu adanya penurunan konsumsi sebesar Rp255.959 atau 0,41\%. Penurunan tersebut terjadi karena kelompok komoditas non pangan juga mengalami penurunan konsumsi rumah tangga, penurunan kelompok komoditas non pangan seperti perumahan dan fasilitas rumah tangga terjadi karena adanya bantuan pemerintah berupa keringanan biaya listrik bagi masyarakat tertentu seperti kategori rumah tangga berdaya listrik 450 Volt yang tidak perlu membayar biaya listrik (gratis) dan 900 Volt yang tidak membayar biaya listrik sepenuhnya (bersubsidi). Namun, selain perumahan dan fasilitas rumah tangga yang didalamnya terdapat sub kelompok komoditas listrik, adapula biaya lainnya seperti biaya pulsa $\mathrm{Hp}$ dan biaya internet yang mengalami peningkatan. Peningkatan terjadi karena adanya kebutuhan akan komunikasi selama beraktivitas 
dari rumah, walaupun memang biaya internet untuk kegiatan pembelajaran dari rumah diberi bantuan berupa kuota gratis dari pemerintah, tetapi tidak bagi pekerja yang bekerja dari rumah atau work from home dimana tetap membutuhkan biaya internet untuk menjalankan aktivitas bekerja nya dari rumah sehingga membutuhkan biaya internet lebih besar dari sebelum Covid-19.

Kelompok komoditas lainnya seperti aneka barang dan jasa juga mengalami perubahan yaitu adanya penurunan konsumsi rumah tangga sebesar Rp200.721 atau 0,6\%. Penurunan tersebut terjadi karena ada bantuan biaya kesehatan, rata-rata masyarakat di lokasi penelitian memiliki bantuan biaya kesehatan berupa BPJS dan KIS, namun adapula masyarakat yang tidak memiliki BPJS dan KIS sehingga mereka tetap mengeluarkan biaya untuk kesehatan (Amridha dkk., 2020). Selanjutnya kelompok komoditas pakaian, alas kaki, dan tutup kepala yang juga mengalami penurunan konsumsi sebesar Rp1.885 atau 1\%. Penurunan terjadi karena kegiatan berbelanja kebutuhan pakaian dan lainnya tidak dilakukan seperti sebelumnya dikarenakan adanya Covid19 yang membuat masyarakat atau responden untuk memilih tidak berbelanja terlebih dahulu seperti mendatangi offline store atau tidak sering seperti sebelumnya, adapula responden yang berbelanja kebutuhan pakaian dan lainnya melalui online shop tetapi hanya beberapa saja. Sedangkan untuk kelompok komoditas barang tahan lama, pajak, pungutan, dan asuransi, serta keperluan pesta dan upacara/kenduri bernilai nol atau tidak ada kegiatan konsumsi dikarenakan peneliti tidak menanyakan hal tersebut kepada responden, selain itu berdasarkan pemahaman peneliti yang bersumber dari Badan Pusat Statistik mengenai biaya untuk kelompok komoditas barang tahan lama, pajak, pungutan, dan asuransi, serta keperluan pesta dan upacara/kenduri tidak dapat dihitung dalam waktu sebulan terakhir, melainkan setahun terakhir, sehingga peneliti memutuskan untuk tidak menanyakan 3 point tersebut kepada responden.

Pola konsumsi yang terjadi di lokasi penelitian sebagian mengalami perubahan yaitu adanya peningkatan dan penurunan. Peningkatan konsumsi adalah bertambahnya jumlah konsumsi yang dihabiskan atau meningkatnya harga yang dibeli responden (harga jual yang tinggi), sedangkan penurunan konsumsi adalah berkurangnya jumlah konsumsi yang dihabiskan dengan harga yang dibeli tetap atau lebih murah. Berdasarkan 61 responden terdapat $7 \%$ mengalami peningkatan dan 93\% mengalami penurunan. Peningkatan dan penurunan pola konsumsi dapat terjadi apabila dilihat dari jumlah konsumsi atau pengeluaran rumah tangga responden. Perubahan pola konsumsi rumah tangga dapat dilihat pada gambar berikut.

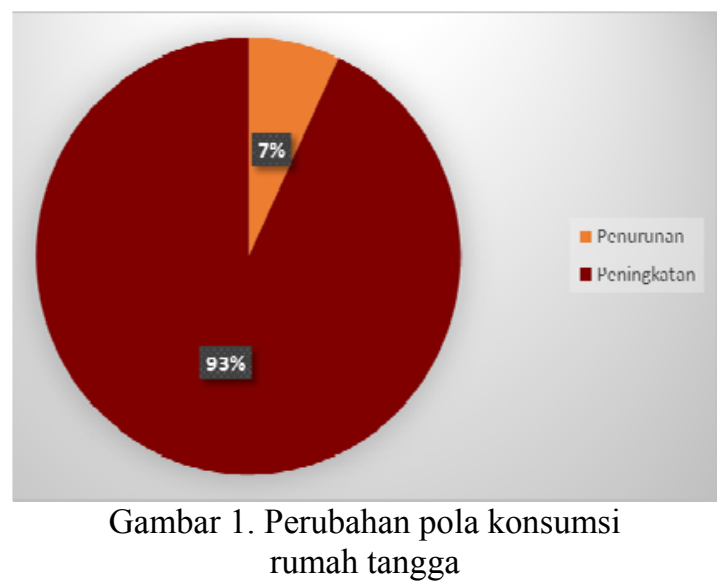

\section{Analisis Hubungan Karakteristik Responden dengan Perubahan Pola Konsumsi Rumah tangga (Crosstabs atau Tabulasi Silang)}

Dalam menganalisis hubungan karakteristik responden dengan perubahan pola konsumsi rumah tangga dapat menggunakan crosstabs atau tabulasi silang. Metode analisis ini dapat menggambarkan hubungan antar variabel. Variabel yang dianalisis terdiri dari umur, jumlah anggota keluarga, pendapatan rumah tangga, pendidikan, pekerjaan suami dan istri, dan Pekerjaan Terdampak karena Covid-19. Selain itu, untuk mempermudah peneliti dalam menganalisis, peneliti menggunakan program statistik yaitu SPSS-26.

\section{Umur}

Umur merupakan lamanya waktu hidup seseorang. Dalam penelitian, umur responden terdiri dari umur produktif yaitu 15-64 tahun dan umur tidak produktif yaitu $<15$ tahun dan $\geq 65$ tahun. Analisis tabulasi silang antara umur dengan perubahan pola konsumsi rumah tangga di RT/RW: 03/02, Kelurahan Drajat dapat dilihat pada Tabel 3. 
Tabel 3. Chi-square test umur dan perubahan pola konsumsi rumah tangga

\begin{tabular}{lccc}
\hline & Nilai & df & $\begin{array}{c}\text { Asymp. Sig. } \\
\text { (2-sided) }\end{array}$ \\
\hline Pearson Chi-square & $0,467^{\mathrm{a}}$ & 1 & 0,494 \\
\hline Likelihood Ratio & 0,858 & 1 & 0,354 \\
\hline $\begin{array}{l}\text { Linear-by-Linear } \\
\text { Association }\end{array}$ & 0,459 & 1 & 0,498 \\
\hline $\mathrm{N}$ & 61 & & \\
\hline
\end{tabular}

Sumber: Data Primer, 2020

Apabila dilihat dari hasil penelitian, dapat dikatakan bahwa umur tidak berhubungan dengan perubahan pola konsumsi rumah tangga, dapat dilihat pada nilai Asym. Sig. (2-sided) $>0,05$ atau $0,49>0,05$ yang artinya $\mathrm{H}_{0}$ diterima dan $\mathrm{Ha}$ ditolak, artinya tidak adanya hubungan antara umur dengan perubahan pola konsumsi rumah tangga.

\section{Jumlah Anggota Keluarga}

Jumlah anggota keluarga adalah banyak sedikitnya orang yang mendiami suatu bangunan secara bersama-sama. Analisis tabulasi silang antara jumlah anggota keluarga dengan perubahan pola konsumsi rumah tangga di RT/RW: 03/02, Kelurahan Drajat dapat dilihat pada Tabel 4.

Apabila dilihat dari hasil penelitian, dapat dikatakan bahwa jumlah anggota keluarga tidak berhubungan dengan perubahan pola konsumsi rumah tangga, dapat dilihat pada Asym. Sig. (2-sided) $>0,05$ atau 0,83 $>0,05$ yang artinya $\mathrm{H}_{0}$ diterima dan Ha ditolak, artinya tidak adanya hubungan antara jumlah anggota keluarga dengan perubahan pola konsumsi rumah tangga.

Tabel 4. Chi-square test jumlah anggota keluarga dan perubahan pola konsumsi rumah tangga

\begin{tabular}{lccc}
\hline & Nilai & df & $\begin{array}{c}\text { Asymp. Sig. } \\
(2-s i d e d)\end{array}$ \\
\hline Pearson Chi-square & $2,821^{\mathrm{a}}$ & 6 & 0,831 \\
\hline Likelihood Ratio & 3,493 & 6 & 0,745 \\
\hline $\begin{array}{l}\text { Linear-by-Linear } \\
\text { Association }\end{array}$ & 0,974 & 1 & 0,324 \\
$\mathrm{~N}$ & 61 & & \\
\hline
\end{tabular}

Sumber: Data Primer, 2020

\section{Pendapatan Rumah Tangga}

Pendapatan rumah tangga adalah penerimaan total yang diterima dan dimiliki seseorang atau suatu rumah tangga yang diperoleh dari berbagai sumber. Analisis tabulasi silang antara pendapatan rumah tangga dengan perubahan pola konsumsi rumah tangga di lokasi penelitian dapat dilihat pada Tabel 5 .

Tabel 5. Chi-square test pendapatan rumah tangga dan perubahan pola konsumsi rumah tangga

\begin{tabular}{lccc}
\hline & Nilai & df & $\begin{array}{c}\text { Asymp. Sig. } \\
\text { (2-sided) }\end{array}$ \\
\hline $\begin{array}{l}\text { Pearson Chi- } \\
\text { square }\end{array}$ & $19,474^{\mathrm{a}}$ & 4 & 0,001 \\
\hline $\begin{array}{l}\text { Likelihood Ratio } \\
\text { Linear-by-Linear } \\
\text { Association }\end{array}$ & 10,637 & 4 & 0,031 \\
\hline $\mathrm{N}$ & 2,683 & 1 & 0,101 \\
\hline
\end{tabular}

Sumber: Data Primer, 2020

Apabila dilihat dari hasil penelitian, dapat dikatakan bahwa pendapatan rumah tangga berhubungan dengan perubahan pola konsumsi rumah tangga, dapat dilihat pada Asym. Sig. (2-sided) $<0,05$ atau $0,001<0,05$ yang artinya $\mathrm{H}_{0}$ ditolak dan $\mathrm{Ha}$ diterima atau adanya hubungan antara pendapatan rumah tangga dengan perubahan pola konsumsi rumah tangga. Hal ini sejalan dengan Silva et al. (2017) yang menyatakan bahwa pendapatan mempengaruhi keberagaman konsumsi pangan rumah tangga.

\section{Pendidikan}

Pendidikan adalah lamanya sekolah yang dijalani seseorang yang nantinya akan bermanfaat dimasa yang akan datang. Analisis tabulasi silang antara pendidikan dengan perubahan pola konsumsi rumah tangga di lokasi penelitian dapat dilihat pada Tabel 6 .

Apabila dilihat dari hasil penelitian, dapat dikatakan bahwa pendidikan responden tidak berhubungan dengan perubahan pola

Tabel 6. Chi-square test pendidikan dan perubahan pola konsumsi rumah tangga

\begin{tabular}{lccc}
\hline & Nilai & df & $\begin{array}{c}\text { Asymp. Sig. } \\
\text { (2-sided) }\end{array}$ \\
\hline $\begin{array}{l}\text { Pearson Chi- } \\
\text { square }\end{array}$ & $3,197^{\mathrm{a}}$ & 3 & 0,362 \\
\hline Likelihood Ratio & 2,863 & 3 & 0,413 \\
\hline $\begin{array}{l}\text { Linear-by-Linear } \\
\text { Association }\end{array}$ & 0,527 & 1 & 0,468 \\
$\mathrm{~N}$ & 61 & & \\
\hline
\end{tabular}

Sumber: Data Primer, 2020 
konsumsi rumah tangga, dapat dilihat pada Asym. Sig. (2-sided) $>0,05$ atau $0,36>0,05$ yang artinya $\mathrm{H}_{0}$ diterima dan Ha ditolak, artinya tidak adanya hubungan antara pendidikan dengan perubahan pola konsumsi rumah tangga.

\section{Pekerjaan}

Pekerjaan adalah kegiatan yang dijalani seseorang demi memperoleh pendapatan. Analisis tabulasi silang antara pekerjaan istri dan pekerjaan suami dengan perubahan pola konsumsi rumah tangga di lokasi penelitian dapat dilihat pada Tabel 7 dan Tabel 8.

\section{Pekerjaan Istri}

Pekerjaan ibu merupakan kegiatan yang dilakukan dengan maksud untuk membantu memperoleh pendapatan di suatu rumah tangga.

Tabel 7. Chi-square test pekerjaan istri dan perubahan pola konsumsi rumah tangga

\begin{tabular}{lccc}
\hline & Nilai & df & $\begin{array}{c}\text { Asymp. Sig. } \\
\text { (2-sided) }\end{array}$ \\
\hline Pearson Chi-square & $1,913^{\mathrm{a}}$ & 4 & 0,752 \\
\hline Likelihood Ratio & 1,696 & 4 & 0,791 \\
\hline $\begin{array}{l}\text { Linear-by-Linear } \\
\text { Association }\end{array}$ & 0,767 & 1 & 0,381 \\
$\mathrm{~N}$ & 61 & & \\
\hline
\end{tabular}

Sumber: Data Primer, 2020

Apabila dilihat dari hasil penelitian, dapat dikatakan bahwa pekerjaan responden tidak berhubungan dengan perubahan pola konsumsi rumah tangga, dapat dilihat pada Asym. Sig. (2-sided) $>0,05$ atau 0,75 $>0,05$ yang artinya $\mathrm{H}_{0}$ diterima dan Ha ditolak, artinya tidak adanya hubungan antara pekerjaan dengan perubahan pola konsumsi rumah tangga.

\section{Pekerjaan Suami}

Menurut Alfian (2016), pekerjaan kepala keluarga dapat memengaruhi jumlah pendapatan yang dimiliki suatu keluarga. Apabila dilihat dari hasil penelitian, dapat dikatakan bahwa pekerjaan suami responden berhubungan dengan perubahan pola konsumsi rumah tangga, dapat dilihat pada Asym. Sig. (2sided $<0,05$ atau $0,049<0,05$ yang artinya $\mathrm{H}_{0}$ ditolak dan $\mathrm{Ha}$ diterima, artinya adanya hubungan antara pekerjaan suami responden dengan perubahan pola konsumsi rumah tangga.

Tabel 8. Chi-square test pekerjaan suami dan perubahan pola konsumsi rumah tangga

Nilai df Asymp. Sig. (2-sided)

\begin{tabular}{lrrr} 
Pearson Chi-square & $9,529^{\mathrm{a}}$ & 4 & 0,049 \\
\hline Likelihood Ratio & 8,159 & 4 & 0,086 \\
\hline $\begin{array}{l}\text { Linear-by-Linear } \\
\text { Association }\end{array}$ & 1,627 & 1 & 0,202 \\
$\mathrm{~N}$ & 61 & &
\end{tabular}

Sumber: Data Primer, 2020

Hasil tersebut sesuai dengan penelitian Alfian (2016) yang menjelaskan bahwa pekerjaan kepala keluarga dapat memengaruhi jumlah pendapatan yang dimiliki suatu keluarga.

\section{Pekerjaan Terdampak karena Covid-19}

Pekerjaan terdampak karena Covid-19 adalah akibat adanya Covid-19 menyebabkan pekerjaan seseorang terdampak. Sedangkan pekerjaan memiliki peranan penting bagi seseorang untuk memperoleh pendapatan, namun dikarenakan adanya Covid-19 ini membuat banyak pekerja yang terdampak. Analisis tabulasi silang antara pekerjaan terdampak karena Covid-19 dengan perubahan pola konsumsi rumah tangga di RT/RW 03/02, Kelurahan Drajat dapat dilihat pada Tabel 9.

Apabila dilihat dari hasil penelitian, dapat dikatakan bahwa Pekerjaan Terdampak karena Covid-19 responden tidak berhubungan dengan perubahan pola konsumsi rumah tangga, dapat dilihat pada Asym. Sig. (2-sided) $>0,05$ atau $0,58>0,05$ yang artinya $\mathrm{H}_{0}$ diterima dan Ha ditolak, artinya tidak adanya hubungan antara pekerjaan dengan perubahan pola konsumsi rumah tangga.

Tabel 9. Chi-square test pekerjaan terdampak karena Covid-19 dan perubahan pola konsumsi rumah tangga

\begin{tabular}{lrrr}
\hline & Nilai & df & $\begin{array}{r}\text { Asymp. Sig. } \\
\text { (2-sided) }\end{array}$ \\
\hline Pearson Chi-square & $0,294^{\mathrm{a}}$ & 1 & 0,588 \\
\hline Likelihood Ratio & 0,311 & 1 & 0,577 \\
\hline $\begin{array}{l}\text { Linear-by-Linear } \\
\text { Association }\end{array}$ & 0,289 & 1 & 0,591 \\
\hline $\mathrm{N}$ & 61 & & \\
\hline
\end{tabular}

Sumber: Data Primer, 2020 


\section{KESIMPULAN DAN SARAN}

Rata-rata konsumsi atau pengeluaran pangan rumah tangga dalam satu bulan ketika sebelum dan selama Covid-19 sebesar Rp748.261 dan Rp688.925. Dapat dikatakan bahwa konsumsi pangan tersebut mengalami penurunan sebesar $0,13 \%$. Sedangkan rata-rata konsumsi atau pengeluaran non pangan rumah tangga dalam satu bulan sebelum dan selama Covid-19 yaitu sebesar Rp1.024.951 dan Rp768.992. Konsumsi non pangan tersebut juga mengalami penurunan sebesar $0,41 \%$. Penurunan konsumsi pangan dan non pangan dapat terjadi karena harga yang dibeli responden cenderung memilih harga yang murah sedangkan jumlah konsumsi cenderung tetap ataupun menurun. Sedangkan peningkatan konsumsi dapat terjadi pada salah satu kelompok komoditas pangan yaitu sayur-sayuran, dikarenakan harga yang dibeli mengalami peningkatan sedangkan jumlah konsumsi cenderung tetap, menurun, dan meningkat.

Tabulasi silang antara karakteristik responden dengan perubahan pola konsumsi rumah tangga yang terjadi dalam penelitian ini adalah pendapatan rumah tangga dan pekerjaan suami yang memiliki hubungan dengan perubahan pola konsumsi rumah tangga, sedangkan variabel lainnya tidak memiliki hubungan dengan perubahan pola konsumsi rumah tangga.

Maka dari itu, bagi responden dan masyarakat di Kelurahan Drajat Kota Cirebon atau lokasi penelitian, diharapkan dapat menanam tanaman-tanaman pangan di pekarangan rumah nya, sehingga pengeluaran rumah tangga dapat lebih hemat dengan memanfaatkan hasil panen dari tanaman yang ditanam, seperti menanam kangkung, dan lainnya.

\section{DAFTAR PUSTAKA}

Alfian, M. D. (2016). Analisis perbandingan pola konsumsi pangan dan non pangan rumah tangga kaya dan miskin di kota makassar [Skripsi]. UIN Alauddin, Makassar.

Alfiati, S. (2018). Analisis faktor-faktor yang memengaruhi pola konsumsi pangan rumah tangga. Photosynthetica, 2(1), 113.

Amridha, Y., Heryanto, M. A., Saefudin, B. R., \& Awaliyah, F. (2020). The analysis of the employee's job satisfaction and performance in private agricultural company. Mahatani: Jurnal Agribisnis (Agribusiness and Agricultural Economics Journal), 2(2), 122-130.

Badan Pusat Statistik. (2018). Statistik Kesejahteraan Rakyat Kota Cirebon 2018. Cirebon: BPS Kota Cirebon.

Badan Pusat Statistik. (2019). Statistik Kesejahteraan Rakyat Kota Cirebon 2019. Kejaksan Dalam Angka. Cirebon: BPS Kota Cirebon.

Badan Pusat Statistik. (2020). Indonesia Triwulan I-2020. Pertumbuhan Ekonomi Indonesia Triwulan I-2020. Berita Resmi Statistik, 39(05), 1-12.

Silva, R. J., Garavello, M. E. D. E., Nardoto, G. B., Mazzi, E. A., \& Martinelli, L. A. (2017). Factors influencing the food transition in riverine communities in the Brazilian Amazon. Environment, Development and Sustainability, 19(3), 1087-1102.

Gerbens-Leenes, P. W., Nonhebel, S., \& Krol, M. S. (2010). Food consumption patterns and economic growth. Increasing affluence and the use of natural resources. Appetite, 55(3), 597-608.

Gilarso, T. (2008). Pengantar Ilmu Ekonomi Makro. Yogyakarta : Kanisius.

Hapsari, H., Sukayat, Y., Djuwendah, E., Deliana, Y., \& Sulistyowati, L. (2019). Consumption Patterns of urban household: Case in Sarimas Regency, Sukamiskin, Bandung. IOP Conference Series: Earth and Environmental Science, 334(1), 012056.

Ismah, K. D. (2020). Pola konsumsi dan ketahanan pangan rumah tangga nelayan di Desa Maja Kecamatan Kalianda 
Bestari, A. P., Noor, T. I. : Perubahan Pola Konsumsi Rumah Tangga Saat Covid-19...

Kabupaten Lampung Selatan. JIIA, 8(1), $39-47$.

Mulyanto. (2005). Kemiskinan dan Kebutuhan Pokok. Jakarta: CV. Rajawali.

Putri, D. W., Sayekti, W. D., \& Rangga, K.K. (2019). Pengambilan keputusan dalam pemilihan sayuran dan pola konsumsi sayuran rumah tangga petani sayuran di Desa Gisting Atas Kecamatan Gisting Kabupaten Tanggamus. JIIA, 7(3), 306313.

Rasmikayati, E., Saefudin, B. R., Kusumo, R. A. B., \& Syamsiyah, N. (2020). Pelatihan pengolahan mangga dan sosialisasi nilai tambahnya sebagai alternatif kegiatan ekonomi di masa pandemi Covid-19. Jurnal Pengabdian Kepada Masyarakat, 4(3), 66-71.

Sari, Y., Rasmikayati, E., Saefudin, B. R., Karyani, T., \& Wiyono, S. N. (2020). Willingness to pay konsumen beras organik dan faktor-faktor yang berkaitan dengan kesediaan konsumen untuk membayar lebih. Forum Agribisnis, 10(1), 46-57.

Sugiyanto, S., \& Pintakami, L. B. (2021). Analysis of factors influencing farmers' household consumption in Malang City, Indonesia. Agricultural Social Economic Journal, 21(02), 155-164. 